\title{
Homogeneous Fat Echotexture
}

National Cancer Institute

\section{Source}

National Cancer Institute. Homogeneous Fat Echotexture. NCI Thesaurus. Code C69212.

A description of homogeneous fat lobules seen in a tissue composition image obtained by sonography. 